\title{
PAX8 EXPRESSION AND ITS ASSOCIATIONS IN PRIMARY RENAL CELL CARCINOMA: A CROSS SECTIONAL STUDY
}

\author{
Ahmed Zamir, Farhan Akhtar*, Samina Waqar*, Aminah Hanif* \\ Armed Forces Institute of Pathology/National University of Medical Sciences (NUMS) Rawalpindi Pakistan, *Army Medical College/ National University of \\ Medical Sciences (NUMS) Rawalpindi Pakistan
}

\begin{abstract}
Objective: To determine the frequency of PAX8 expression in cases of primary renal cell carcinoma (RCC) and its association with patient demographics and tumor type.

Study Design: Cross sectional study.

Place and Duration of Study: Department of Histopathology, Armed Forces Institute of Pathology, Rawalpindi, from Jun 2016 to Jun 2017.

Methodology: After ethics approval, 57 cases were selected by non probability consecutive sampling. Inclusion criteria was diagnosis of primary renal cell carcinoma of all histological types, in both genders, among adults aged $>18$ years. Exclusion criteria were poorly fixed specimens and metastatic renal cell carcinoma. The main outcome measure was PAX8 frequency in renal cell carcinoma. The secondary outcome measure was correlation of PAX8 expression with age, gender, tumor type and grade. Data was entered and analyzed on Statistical Package for the Social Sciences.

Results: Out of 57 cases, majority were males $37,(64.9 \%)$. The mean age was $55.35 \pm 12.60$ years. Clear cell carcinoma was the most frequent histopathologic variant in $47(81 \%)$ cases followed by papillary carcinoma in $6(10.2 \%)$, chromophobe cell carcinoma $2(3.5 \%)$, sarcomatoid renal carcinoma $1(1.75 \%)$ and mucinous tubular and spindle cell carcinoma $1(1.75 \%)$. PAX8 expression was positive in $52(91.2 \%)$. No significant difference was found in the frequency of PAX8 expression across age $(p=0.321)$, gender $(p=1.00)$ and tumor type $(p=1.00)$. There was significant difference seen across tumor grade $p=0.03$.

Conclusion: PAX8 is an important additional diagnostic marker for renal cell carcinoma. It can be recommended for inclusion in immunohistochemical panel for diagnosis of primary renal neoplasms in histopathology laboratory settings.
\end{abstract}

Keywords: Immunohistochemistry, PAX8 expression, Renal cell carcinoma.

\footnotetext{
This is an Open Access article distributed under the terms of the Creative Commons Attribution License (http://creativecommons.org/licenses/by/4.0), which permits unrestricted use, distribution, and reproduction in any medium, provided the original work is properly cited.
}

\section{INTRODUCTION}

In the western countries, renal cell carcinoma (RCC) is the $10^{\text {th }}$ most common cancer. Incidence of RCC is higher in Whites as compared to Asians. RCC occurs more frequently in male population in developed countries ${ }^{1}$. In European Union, incidence of RCC is 15.8 per 100000 in males and 7.1 per 100000 in females. Globally, 270000 cases of renal tumors are diagnosed per year and 116000 people die fromthis disease. As compared to the western population, renal cell carcinoma is $13^{\text {th }}$ most common tumor worldwide ${ }^{2}$.

The risk factors include demographic, lifestyle, iatrogenic and genetic ${ }^{3}$. The demographic factors are race, age and gender. The incidence is substantially lower in Asian countries compared to United States. The lowest incidences have been reported in African countries. In Europe and United States, incidence increase consistently with age ${ }^{4}$. The lifestyle factors are obesity and smoking. The iatrogenic factors are hypertension, diabetes, acquired renal cystic disease and urinary tract infection ${ }^{5}$.

Correspondence: Dr Farhan Akhtar, Consultant Histopathologist, Department of Pathology, AM College Pakistan

Received: 04 Nov 2019; revised received: 01 Sep 2020; accepted: 10 Sep 2020
PAX genes are a family of cell lineage-restricted transcription factors. These play a fundamental role in organogenesis and are regulatoryproteins. PAX8 is a nephric lineage transcription factor that is critical for organogenesis of kidney, thyroid gland and mullerian system. These proteins are required for cell growth and differentiation in embryonic tissues ${ }^{6}$. Recently PAX8 has been shown to be expressed in a high percentage in renal cell tumors. Review of literature shows that in a study carried out in Texas USA, PAX8 expression was observed in $82 \%$ of primary renal cell carcinomas 7 . A study done in China in 2013 showed that PAX8 has high sensitivity in diagnosing renal cell tumor ${ }^{4,8}$.

This study was done to assess the frequency of PAX8 expression in primary renal cell carcinoma and determine the associations of PAX8 expression on immunohistochemistry (IHC) in renal cell carcinoma.

\section{METHODOLOGY}

A cross-sectional study was conducted in the department of Histopathology, Armed Forces Institute of Pathology (AFIP), Rawalpindi. It is a tertiary care institute, offering nearly all kinds of latest diagnostic facilities. Prior to start of study, the project was 
approved by the ethics review committee of the institute. Total duration of the study was one year. Research work was carried out from June 2016 to June 2017.

Sample size of 57 was calculated with $95 \%$ confidence level and $12 \%$ margin of error while taking expected percentage of PAX8 expression to be $82 \%^{3}$ in patients with renal cell carcinoma. Sample size was calculated using WHO sample size calculator.

Patients were selected by non-probability, consecutive sampling. A total of 57 cases of renal cell carcinoma were studied. Cases with ages 25-80 years from both genders diagnosed with primary renal cell carcinoma of all histological types were included in the study. Exclusion criteria were biopsies from metastatic sites of renal cell carcinoma and poorly fixed specimens.

The data collection proforma of the patients with RCC cases were selected as per inclusion criteria. Clinical details like age, gender tumour grade and histopathological details like tumour type were noted. The formalin fixed paraffin embedded (FFPE) tissue sections of renal cell carcinoma were taken and PAX8 immunohistochemistry assay was performed.

For PAX8 immunohistochemistry the FFPE tissue sections were cut at $3 \mu \mathrm{m}$ thickness and placed on clean glass slide with pre-attatched adhesive on its surface. They were incubated at 58 degrees Celsius for 4 hours. The sections were deparaffinized with xylene 1 and 2, for 3 minutes each. They were rehydrated in decreasing concentrations of alcohol, $90 \%, 80 \%$ and $70 \%$ for 3 minutes each followed by running tap water for 5 seconds. The slides were placed in coplin jar with $0.01 \mathrm{M}$ Tris-EDTA buffer at $\mathrm{pH}$ of $9.0 .750 \mathrm{~W}$. The domestic microwave was used to treat the slides for 20-30 minutes for heat mediated antigen retrieval.

Slides were washed with distilled water for 20-40 minutes. After cooling down the sections, they were brought to PBS at pH 7.3 for 5 minutes. PBS was washed and excess was wiped off the sections. Endogenous peroxidase activity blocked by incubating in $0.5 \%$ hydrogen peroxide in methanol for 5 minutes. The slides were washed in three series of PBS, 2 minutes each. Primary antibody (100 uL) of PAX8 (Clone by Merck) was instilled on the sections and incubated for 60 minutes. The slides were again washed in three series of PBS, for 60 minutes. Then they were incubated in avidin-biotin complex for 10 minutes. They were rinsed with distilled water. They were incubated in $\mathrm{DAB}$ (diaminobenzidine) substrate solution for 5 minutes. Then the slides were washed with water and counter stained with haematoxylin for 40 seconds. The slides were dehydrated by placing them in increasing concentrations of alcohol, $70 \%, 80 \%, 90 \%$ and $100 \%$ alcohol for 3 minutes each. Clearing was done by placing slides in xylene for 3 minutes. The slides were mounted with Canada balsam.

All the collected data was entered and analyzed through SPSS version 20 .

Numerical variables like age was presented by mean \pm SD. Categorical variables namely age, gender, tumor type, tumor grade and PAX8 expression were presented as frequency and percentages. Data was stratified for age, gender and type of carcinoma to address effect modifiers. Post stratification chi-square test was applied taking $p$-value $\leq 0.05$ as significant.

\section{RESULTS}

A total of 57 cases of renal cell carcinoma were included in the study. The ages of patients ranged from $25-80$ years with mean age of $55.35 \pm 12.60$ years. In this study, most of the patients were in the $5^{\text {th }}$ and $6^{\text {th }}(75 \%)$ decade of life (table-I). Majority of the patients in this study were males 37 (64.9\%) table-II.

Table-I: PAX8 expression and patient age (years).

\begin{tabular}{|c|c|c|}
\hline $\begin{array}{l}\text { Age groups in } \\
\text { years }\end{array}$ & $\begin{array}{c}\text { PAX8 Negative } \\
(n=5)\end{array}$ & $\begin{array}{c}\text { PAX8 Positive } \\
(n=52)\end{array}$ \\
\hline $25-50$ years & $4(7 \%)$ & $16(28 \%)$ \\
\hline $51-80$ years & $1(1.8 \%)$ & $36(63 \%)$ \\
\hline Total Cases & 5 & 52 \\
\hline \multicolumn{3}{|c|}{ Table-II: PAX8 expression and patient gender. } \\
\hline & $\begin{array}{c}\text { PAX8 Negative } \\
(n=5)\end{array}$ & $\begin{array}{c}\text { PAX8 Positive } \\
(n=52)\end{array}$ \\
\hline Male & $3(5.3 \%)$ & $34(59.7 \%)$ \\
\hline Female & $2(3.5 \%)$ & $18(31.5 \%)$ \\
\hline Total Cases & $5(8.8 \%)$ & $52(91.2 \%)$ \\
\hline \multicolumn{3}{|c|}{ Table-III: PAX8 expression and renal cell carcinoma type } \\
\hline & $\begin{array}{c}\text { PAX8 Negative } \\
(n=5)\end{array}$ & $\begin{array}{c}\text { PAX8 Positive } \\
(n=52)\end{array}$ \\
\hline Clear cell RCC & $5(8.7 \%)$ & $42(73.6 \%)$ \\
\hline Papillary RCC & 0 & $6(10.5 \%)$ \\
\hline Chromophobe RCC & 0 & $2(3.5 \%)$ \\
\hline Sarcomatoid RCC & 0 & $1(1.7 \%)$ \\
\hline $\begin{array}{l}\text { Mucinous tubular } \\
\text { and spindle cell RCC }\end{array}$ & 0 & $1(1.7 \%)$ \\
\hline
\end{tabular}

Renal cell carcinoma subtyping revealed that clear cell carcinoma was the most frequent histopathologic variant in 47 (81\%) cases (fig- 1 ). This was followed by papillary carcinoma which was observed in 6 cases $(10.2 \%)$, chromphobe cell carcinoma 2 (3.5\%) cases, sarcomatoid renal carcinoma 1 (1.75\%), mucinous tubular and spindle cell carcinoma 1 (1.75\%) case 
(table-III). PAX8 expression was positive in 52 (91.2\%) patients (fig-2). There was no significant difference found in the frequency of PAX8 expression across age $(p=0.321)$, gender $(p=1.00)$ and tumor type $(p=1.00)$ groups. There was significant difference across tumor grade $(p=0.03)$ group seen.

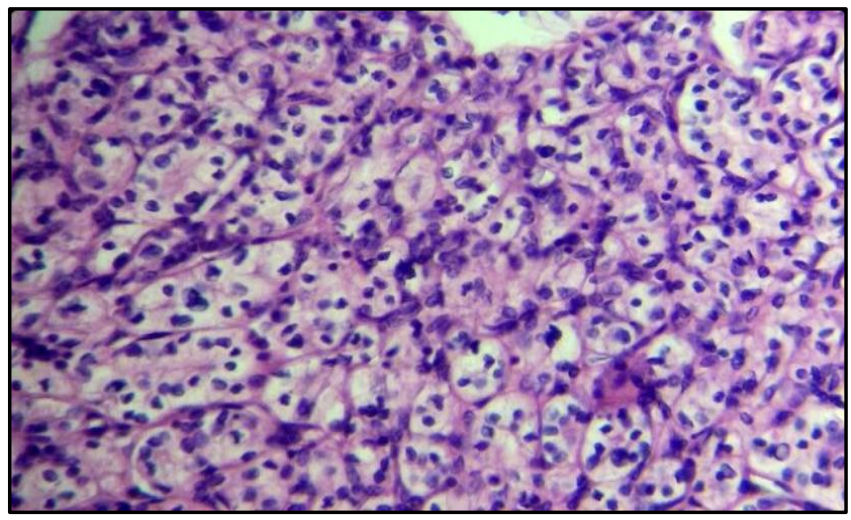

Figure-1: Clear cell renal cell carcinoma (H\&E 20x).

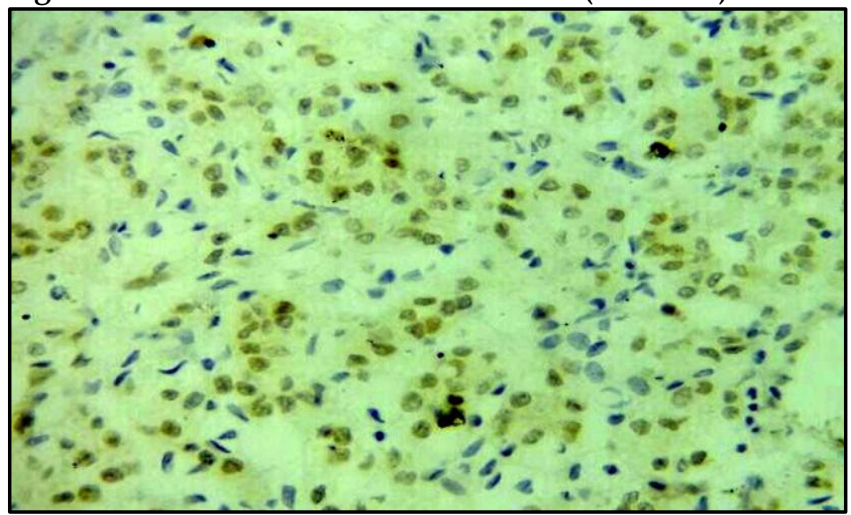

Figure-2: PAX8 expression in clear cell renal cell carcinoma (PAX8 IHC 20x).

\section{DISCUSSION}

Paired-box genes (PAX) encode a family of nine well-characterized paired-box transcription factors (PAX1-9), which are critical for embryogenesis ${ }^{9}$. PAX proteins are considered to be involved in regulation of organogenesis and play an important role in maintenance of pluripotency of stem cell populations during human development. Among these paired-box genes, it has been hypothesized that PAX8 has a crucial role in the development of the thyroid gland, kidneys, brain, eyes and Mullerian system in determining cell fate as well as regulating expression of the suppressor gene for Wilms' tumor $6,7,10$. Tacha et al ${ }^{6}$ in 2011 have reported that PAX8 is not only expressed in thyroid, kidneys, brain, eyes and Mullerian system but also found in high levels in some specific types of tumors of thyroid, kidneys and pancreatic neuroendocrine tumors. These facts indicate that PAX8 expression can be used in screening and risk stratification of patients $^{11}$. The existing research on the frequency of PAX8 expression in primary renal cell carcinoma was limited but no such local published material was available which necessitated the present study.

In present study, the mean age of the patients was $55.35 \pm 12.60$ years. Rana et al in 2015 reported similar mean age of $52.38 \pm 12.58$ years among patients presenting at Sheikh Zayed Hospital Lahore with renal cell carcinoma ${ }^{12}$. An analogous mean age of $55 \pm 15$ years has also been reported by Sidharth et al, in 2011 among such patients in Nepal. Ray in 2016 reported similar mean age of $52.79 \pm 13.47$ years among Indian patients with renal cell carcinoma while Oglio reported it to be $59 \pm 12$ years in Brazilian such patients ${ }^{13,14}$.

Majority of the patients were aged between 53-80 years $37,(64.9 \%)$. Our observation is in line with that of Rana et al who also noticed that $60 \%$ of the RCC patients were aged 50 years and above. Sidharth et al reported that $86 \%$ of the Nepalese patients with renal cell carcinoma were aged above 40 years. Similar observation was made by Ray et al in India who reported that $73.33 \%$ of such patients were between $40-80$ years of age ${ }^{14}$.

In the present study, there were $37(64.9 \%)$ male and $20(35.1 \%)$ female patients with a male to female ratio of 1.9:1. A matching male predominance among such patients has been observed by local study in which the ratio reported was 1.5:13. Humera et al also mentioned similar male dominance among such patients with male to female ratio of 2:1 at Jinnah Post graduate Medical Centre Karachi ${ }^{15}$. Sidharth et al ${ }^{13}$ in Nepal (1.7:1), Ray et al in India ${ }^{14}$ (2.1:1) and Oglio et al in Brazil (2.7:1) also reported similar male predominance among patients of renal cell carcinoma ${ }^{16}$.

Clear cell carcinoma was the most frequent and was observed in $47(81 \%)$ cases followed by papillary carcinoma which was observed in $6(10.2 \%)$ cases. Humera reported similar frequency of clear cell $(70 \%)$ and papillary $(16.66 \%)$ carcinoma among such patients at Jinnah Postgraduate Medical Centre Karachi ${ }^{15}$. A similar frequency of clear cell $(84 \%)$ and papillary (12\%) carcinoma has been reported previously in local population by Rana ${ }^{12}$.

PAX8 expression was positive in 52 (91.2\%) cases. No significant difference in the frequency of PAX8 expression across age $(p=0.321)$, gender $(p=1.00)$ and tumor type $(p=1.00)$ groups was found. Although, there was significant difference across tumor grade 
$p=0.03$ group was seen. A similar frequency of $82 \%$ to $89 \%$ has been reported for PAX8 expression by Ozcan et al, among American patients with renal cell carcino$\mathrm{ma}^{17}$. Knoepp et al, in 2012 also observed similar frequency of $88.0 \%$ among American patients ${ }^{11}$. Bar et al in 2015 reported PAX8 positivity of $96 \%$ in normal renal tissue and $83 \%$ in renal tumors ${ }^{18}$. Overall intensity of PAX8 expression was significantly higher in metastatic RCC as compared to primary tumorsin their study while Albadine et al, 2010 reported this frequency to be $90.0 \%$ in Turkey ${ }^{10,17,19}$.

\section{CONCLUSION}

In our study, vast majority of patients with RCC had PAX8 expression with significant association to tumor grade. PAX8 is an important additional diagnostic marker for RCC and can be considered for inclusion in immuno-histochemical panel to assist in diagnosis of primary renal neoplasms in histopathology laboratory settings.

\section{CONFLICT OF INTEREST}

This study has no conflict of interest to be declared by any author.

\section{REFERENCES}

1. Capitanio U, Bensalah K, Bex A, Boorjian S A, Bray F, Coleman J, Gore J L, Sun M, et al. Epidemiology of renal cell carcinoma. Eur Urol 2019; (75)1: 74-84.

2. Znaor A, Lortet-Tieulent J, Laversanne M, Jemal A, Bray F. International variations and trends in renal cell carcinoma incidence and mortality. Eur Urol 2015; 67(3): 519-30.

3. Escudier B, Porta C, Schmidinger M, Rioux-Leclercq N, Bex A, Khoo V, et al. ESMO Guidelines Committee. Renal cell carcinoma: ESMO Clinical Practice Guidelines for diagnosis, treatment and follow-up. Ann Oncol 2016; 27(Suppl-5): v58-v68.

4. Rossi SH, Klatte T, Smith JU, Stewart GD. Epidemiology and screening of renal cancer. World J Urol 2018; 36(9): 1341-53.

5. Cumberbatch MG, Rota M, Catto JW, La Vecchia C. The role of tobacco smoke in bladder and kidney carcinogenesis: A comparison of exposures and metanalysis of incidence and mortality risks. Eur Urol 2016; 70(3): 458-66.

6. Tacha D, Zhou D, Cheng L. Expression of PAX8 in normal and neoplastic tissues: a comprehensive immunohistochemical study. Appl Immunohistochem Mol Morphol 2011; 19(4): 293-99.

7. Ozcan A, de la Roza G, Ro JY, Shen SS, Truong LD. PAX2 and PAX8 expression in primary and metastatic renal tumors: a comprehensive comparison. Arch Pathol Lab Med 2012; 136(12): 1541-51.

8. Zhang W, Yu WJ, Xia Y, Liu Y, Liu XL, Zhuang J, et al. Expression of carbonic anhydrase IX, PAX2 and PAX8 and their association with clinicopathologic characteristics in renal epithelial tumors. Chinese J Pathol 2013; 42(7): 442-45.

9. Muratovska A, Zhou C, He S, Goodyer P, Eccles MR. Paired-Box genes are frequently expressed in cancer and often required for cancer cell survival. Oncogene 2003; 22(39): 7989-97.

10. Mittag J, Winterhager E, Bauer K, Grümmer R. Congenital hypothyroid female PAX8-deficient mice are infertile despite thyroid hormone replacement therapy. Endocrinol 2007; 148(2): 719-25.

11. Knoepp S, Kunju L, Roh M. Utility of PAX8 and PAX2 immunohistochemistry in the identification of renal cell carcinoma in diagnostic cytology. Diagn Cytopathol 2010; 40(8): 667-72.

12. Rana A, Ashraf S, Rahim J, Hussain N, Jamil MN, Tahir MM. Clinical presentation of renal cell carcinoma. J Ayub Med Coll Abbottabad 2015; 27(2): 326-28.

13. Sidharth, Luitel BR, Gupta DK, Maskey P, Chalise PR, Sharma UK, et al. Patern of renal cell carcinoma - a single center experience in Nepal. Kathmandu Uni Med J 2011; 35(3): 185-88.

14. Ray RP, Mahapatra RS, Khullar S, Pal DK, Kundu AK. Clinical characteristics of renal cell carcinoma: five years review from a tertiary hospital in eastern India. Indian J Cancer 2016; 53(1): 114-17.

15. Humera, Ali S, Kehar SI. Morphological variants of renal carcinoma in radical nephrectomy specimens. J Coll Physicians Surg Pak 2015; 25(9): 654-57.

16. Nguyen DP, Vertosik EA, Corradi RB, Vilaseca A, Binfanti NE, Toujier KA, et al. Histologic subtype of Renal cell Carcinoma significantly impacts survival in the era of partial nephrectomy. Urol Oncol 2016; 34(6): 259.e1-259.e8.

17. Ozcan A, Shen SS, Hamilton C, Anjana K, Coffey D, Krishnan B, et al. PAX 8 expression in non-neoplastic tissues, primary tumors, and metastatic tumors: a comprehensive immunohistochemical study. Mod Pathol 2011; 24(6): 751-64.

18. Barr LM, Jilaveanu BL, Camp LR, Adeniran JA, Kluger HM, Sush B. PAX8 expression in renal tumors and distant sites: a useful marker of primary and metastatic renal cell carcinomas. J Clin Pathol 2015; 68(1): 12-17.

19. Albadine R, Schultz L, Illei P, Ertoy D, Hicks J, Sharma R, et al. PAX8 (+)/p63 immunostaining pattern in renal collecting duct carcinoma (CDC). Am J Surgical Pathol 2010; 34(7): 965-69. 